\title{
Fatty Acid Composition of Some Mycolic Acid-containing Coryneform Bacteria
}

\author{
By M. D. COLLINS, ${ }^{1 *}$ M. GOODFELLOW ${ }^{2}$ AND D. E. MINNIKIN ${ }^{3}$ \\ ${ }^{1}$ Department of Microbiology, National Institute for Research in Dairying, Shinfield. \\ Reading RG2 9AT, U.K. \\ ${ }^{2}$ Department of Microbiology, The University, Newcastle upon Tyne NEI 7RU, U.K. \\ ${ }^{3}$ Department of Organic Chemistry, The University, Newcastle upon Tyne NE1 7RU, U.K.
}

(Received 19 January 1982; revised 9 April 1982)

The fatty acid profiles of 74 strains of mycolic acid-containing coryneform bacteria were examined by gas-liquid chromatography. All of the strains contained major amounts of straightchain and monounsaturated fatty acids although some also possessed substantial amounts of 10methyloctadecanoic acid. Iso- and anteiso-branched acids were not present. Five distinct fatty acid patterns were evident: (i) Corynebacterium diphtheriae, $C$. pseudotuberculosis and ' $C$. ulcerans' strains contained major amounts of hexadecanoic and hexadecenoic acids; (ii) $C$. glutamicum, $C$. xerosis and related saprophytic and animal-associated strains, predominantly hexadecanoic and octadecenoic acids; (iii) C. bovis, major amounts of octadecenoic and 10methyloctadecanoic acids; (iv) ' $C$. mycetoides', significant amounts of heptadecanoic acid as well as hexadecanoic and octadecenoic acids; and (v) strains related to Rhodococcus possessed significant quantities of 10-methyloctadecanoic acid in addition to straight-chain and monounsaturated acids.

\section{INTRODUCTION}

Lipid markers are being increasingly used in the classification and identification of coryneform and related taxa (Minnikin et al., 1978). The most productive studies to date have involved analyses of mycolic acids (Goodfellow et al., 1976; Keddie \& Cure, 1977; Collins et al., 1982) and isoprenoid quinones (Yamada et al., 1976; Collins et al., 1977, 1979). The use of simple long-chain fatty acids as chemotaxonomic markers in coryneform taxonomy has received less attention, although preliminary data are encouraging (Minnikin et al., 1978, 1979; Collins \& Jones, 1980; Collins et al., 1980).

The simple non-hydroxylated fatty acids of coryneform bacteria are conventional in type and generally fall into two broad patterns, those containing high proportions of straight-chain and monounsaturated acids and those with high proportions of iso- and anteiso-methyl branchedchain acids (Minnikin et al., 1978). Preliminary data indicate that mycolic acid-containing coryneform bacteria fall into the first category, whereas those taxa lacking mycolic acids contain substantial amounts of branched-chain acids. The single report (Brennan \& Lehane, 1971) of high proportions of iso- and anteiso- acids in mycolic acid-containing strains labelled Corynebacterium diphtheriae and C. pseudotuberculosis has not been substantiated. Mycolic acidcontaining strains assigned to the genera Mycobacterium, Nocardia and Rhodococcus, however, contain 10-methyloctadecanoic acid (tuberculostearic acid) in addition to the simple straightchain and monounsaturated acid types (Kroppenstedt \& Kutzner, 1978; Minnikin et al., 1978).

In the present study the fatty acid composition of 74 strains of mycolic acid-containing coryneform bacteria was determined. 


\section{METHODS}

Cultures and cultivation. Details of the test strains and their sources are given in Table 1. Most of the strains were grown in shake flasks of nutrient broth no. 2 (Oxoid) for 3 to $5 \mathrm{~d}$ at $30^{\circ} \mathrm{C}$. In the case of the Corynebacterium bovis strains the medium was supplemented with Tween $80(0.2 \%, \mathrm{v} / \mathrm{v})$. Cultures were checked for purity at maximum growth, killed with formaldehyde $(1 \%, v / v)$, harvested by centrifugation $(10000 \mathrm{~g})$, washed with distilled water and freeze-dried.

Extraction and analysis of fatty acids. Dried organisms (about $50 \mathrm{mg}$ ) were degraded by acid methanolysis after Minnikin et al. (1975). Fatty acid methyl esters were isolated by preparative thin-layer chromatography on layers $(1 \mathrm{~mm})$ of Merck silica gel $\mathrm{PF}_{254+366}$ using petroleum ether (b.p. $\left.60-80^{\circ} \mathrm{C}\right) /$ diethyl ether $(85: 15$, v/v) as developing solvent. A Perkin-Elmer F11 flame ionization gas chromatograph fitted with stainless steel columns (4 mm o.d.) was used, with nitrogen as carrier gas, for the analysis of the purified fatty acid methyl esters. Analyses were performed using both non-polar $(2 \mathrm{~m}, 2.5 \% \mathrm{OV}-1$ silicone on 80-100 mesh Chromosorb G.AW-DMCS, $180^{\circ} \mathrm{C}$; Phase Separations) and polar ( $2 \mathrm{~m}, 3 \%$ Silar-5CP on 80-100 mesh Gas-chrom A, $160^{\circ} \mathrm{C}$; Applied Science Laboratories) columns. The identity of individual esters was established by comparison of the retention times with those of standard straight-chain and monounsaturated esters. Identification of fatty acid esters was also assisted by calculation of equivalent chain lengths (Miwa et al., 1960) for each stationary phase employed. The relative proportions of the fatty acid esters were estimated by calculating the product of the retention time and peak height for each component in a sample and taking percentages of the sum of the products for all the components (Kates, 1972).

\section{RESULTS AND DISCUSSION}

Results of the gas-liquid chromatographic analysis of the non-hydroxylated long-chain fatty acid methyl esters of the test strains are shown in Table 2 . All of the strains contained major amounts of straight-chain and monounsaturated fatty acids. Iso- and anteiso-branched acids were not detected, although in some strains 10-methyl-branched acids (e.g. tuberculostearic acid) were present in substantial amounts (see Table 2).

The test strains were divided into five groups on the basis of their fatty acid profiles. Corynebacterium diphtheriae, $C$. pseudotuberculosis and ' $C$. ulcerans' contained major amounts of hexadecanoic $\left(\mathrm{C}_{16: 0}\right)$ and hexadecenoic $\left(\mathrm{C}_{16: 1}\right)$ acids with octadecenoic acid $\left(\mathrm{C}_{18: 1}\right)$ present in only small amounts (Table 2 ). In contrast, the animal-associated corynebacteria (e.g. $C$. kutscheri, C. pseudodiphtheriticum, $C$. xerosis), saprophytic glutamic acid-producing strains (e.g. Brevibacterium divaricatum, 'B. flavum', 'B. chang-fua', 'B. immariophilum', 'B. lactofermentum', 'B. roseum', 'B. saccharolyticum', 'C. acetoacidophilum', $C$. callunae, $C$. glutamicum, 'C. herculis', $C$. lilium, 'C. melassecola') and Bacterionema matruchotii contained major amounts of hexadecanoic $\left(C_{16: 0}\right)$ and octadecenoic $\left(\mathrm{C}_{18: 1}\right)$ acids (Table 2). The close relationship found between $C$. diphtheriae, $C$. pseudotuberculosis and ' $C$. ulcerans' is of interest as strains assigned to these species are the only known corynebacteria able to produce diphtheria toxin upon lysogenization with the beta phage of $C$. diphtheriae (Maximescu et al., 1974). Additional representatives of the $C$. diphtheriae and $C$. glutamicum groups need to be examined to determine whether the differences in fatty acid profiles can be weighted for diagnostic purposes. The fatty acid data on the Bacterionema matruchotii strains are similar to those obtained in an earlier and more extensive study (Alshamaony et al., 1977). These data do not contradict the suggestion (Collins, 1982; Goodfellow et al., 1982b) that B. matruchotii should be reclassified in the genus Corynebacterium sensu stricto.

The $C$. bovis strains were distinguished from all of the other true corynebacteria as they contained major amounts of octadecenoic and 10-methyloctadecanoic acids. Lechevalier $e t$ al. (1977) previously detected 10-methyloctadecanoic acid in a strain of this organism. Corynebacterium bovis also has significantly shorter mycolic acids (about $\mathrm{C}_{22}$ to $\mathrm{C}_{32}$ ) than those of other corynebacteria (about $\mathrm{C}_{28}$ to $\mathrm{C}_{36}$; Collins et al., 1982) and is sharply separated from other species of Corynebacterium sensu stricto in numerical phenetic surveys (Jones, 1975; Goodfellow et $a l ., 1982 b$ ). The $C$. bovis strains are also unusual as they contain small amounts of fatty acids with chromatographic properties of monounsaturated acids (i.e. $C_{11: 1}, C_{12: 1}, C_{13: 1}, C_{14: 1}$, $\mathrm{C}_{15: 1}, \mathrm{C}_{16: 1}$ and $\left.\mathrm{C}_{17: 1}\right)$. 'Corynebacterium mycetoides' $\mathrm{C} 63$ also formed a distinct pattern as it contained substantial amounts of $C_{17: 0}$ in addition to $C_{16: 0}$ and $C_{18: 1}$ (Table 2). The presence of high proportions of odd-numbered straight-chain acids is unusual, but the mycolic acids of 
Table 1. Designation and sources of test strains

Laboratory no.

D6

D87

C228

$\mathrm{C} 112$

$\mathrm{D} 2 \dagger$

B53†

B60

C80

C790

C794

D3

C 81

$\mathrm{C} 123 \dagger$

$\mathrm{C} 260$

C124

$\mathrm{C} 113$

C82

C127

C188

C $357+$, C 358

C129

D901

$\mathrm{C} 12 \dagger, \mathrm{C} 873$

C130†

C13, C66, C67

C39, $\mathrm{C} 104$

D4

D7

$\mathrm{C} 85+$

D8†

C20, C59

C133

C136

C63

D24†, D24B

$\mathrm{C} 265+$

$\mathrm{C} 73$

C150, C152, C153, $\mathrm{C} 155, \mathrm{C} 215$

\section{$\mathrm{C} 17+$}

$\mathrm{C} 190 \dagger$

$\mathrm{C} 170, \mathrm{C} 172, \mathrm{C} 174, \mathrm{C} 176$,

$\mathrm{C} 178, \mathrm{C} 179, \mathrm{C} 180$

C137

C234

C237

C239

$\mathrm{N} 744 \dagger$

$\mathrm{C} 7 \dagger, \mathrm{C} 24, \mathrm{C} 56, \mathrm{C} 57, \mathrm{C} 58$,

D19-D22, R59, R71†

N31
Strain and source*

'Arthrobacter albidus'; NCIB 10266

'Arthrobacter hydrocarboglutamicus'; ATCC 15583

'Arthrobacter paraffineus'; NCIB 10699

'Arthrobacter roseoparaffinus'; NCIB 10700

Arthrobacter variabilis; NCIB 9455

Bacterionema matruchotii; NCIB 10254

Bacterionema matruchotii; Dr G. H. Bowden, Dept of Dental Bacteriology, The London Hospital Dental Institute, London: J1163

Brevibacterium ammoniagenes; NCIB 8143

'Brevibacterium butanicum'; ATCC 21196

'Brevibacterium chang-fua'; ATCC 14017

Brevibacterium divaricatum; NCIB 9379

'Brevibacterium flavum'; NCIB 9565

'Brevibacterium immariophilum'; NCIB 9544

'Brevibacterium ketoglutamicum'; DSM 20165

'Brevibacterium lactofermentum'; NCIB 9567

'Brevibacterium paraffinolyticum'; NCIB 11160

'Brevibacterium roseum'; NCIB 9654

'Brevibacterium saccharolyticum'; NCIB 9543

'Brevibacterium sterolicum'; NCIB 11161

Caseobacter polymorphus; NCDO 2097, NCDO 2099

'Corynebacterium acetoacidophilum'; NCIB 9661

'Corynebacterium alkanum'; ATCC 21194

Corynebacterium bovis; NCTC 3224, NCDO 1931

Corynebacterium callunae; NCIB 10338

Corynebacterium diphtheriae; NCTC 3985, NCTC 3529, NCTC 10681

Corynebacterium fascians; ATCC 12974, NCPPB 1488

Corynebacterium flavescens; NCIB 8707

Corynebacterium glutamicum; NCIB 10025

'Corynebacterium herculis'; NCIB 9694

'Corynebacterium hydrocarboclastus'; Dr K. Komagata, Ajinomoto Co., Kawasaka, Japan: AJ 1386

Corynebacterium kutscheri; NCTC 949; NCTC 1386

Corynebacterium lilium; NCIB 10337

'Corynebacterium melassecola'; NCIB 10336

'Corynebacterium mycetoides'; NCTC 9864

'Corynebacterium minutissimum'; NCTC 10288, NCTC 10285

Corynebacterium paurometabolum; DSM 20162

Corynebacterium pseudodiphtheriticum; Dr D. Jones, Dept of Microbiology,

University of Leicester: $\mathrm{C} 10$

Corynebacterium pseudotuberculosis; Dr H. R. Carne, Dept of Pathology,

University of Cambridge: Ov 1134 (ovine strain), Cap 16 (caprine strain), Cap 16F302-4 (caprine strain), E107 (equine strain), NCTC 4681

Corynebacterium renale; NCTC 7448

'Corynebacterium rubrum'; NCIB 9433

'Corynebacterium ulcerans'; Dr H. R. Carne: JW2, JW7, JW33, JW40 (bovine strains), PM39C, PM298G, PM319C (equine strains)

Corynebacterium xerosis; NCIB 9956

'Mycobacterium flavum subsp. methanicum'; NCIB 9738

'Mycobacterium lacticolum'; NCIB 9740

'Mycobacterium rubrum subsp. propanicum'; NCIB 9741

Rhodococcus coprophilus; NCIB 11211

Rhodococcus equi; NCTC 1621, NCTC 10673 (Corynebacterium hoagii),

NCTC 5649, NCTC 5650, NCTC 4219, Dr H. R. Carne: UNP 20343, Jeffcott I, 149,1499, ATCC 25715, ATCC 25729

Rhodococcus rhodochrous; Dr R. E. Gordon, Institute of Microbiology, Rutgers

University, New Jersey, U.S.A.: W21

* ATCC, American Type Culture Collection, Rockville, Md, U.S.A.; DSM, Deutsche Sammlung von Microorganismen, Teilsammlung Darmstadt, 61, Darmstadt, F.R.G. NCDO, National Collection of Dairy Organisms, Shinfield, U.K.; NCIB, National Collection of Industrial Bacteria, Torry Research Station, Aberdeen, U.K.; NCPPB, National Collection of Plant Pathogenic Bacteria, Harpenden, Herts., U.K.; NCTC, National Collection of Type Cultures, London, U.K.

Species not included in the Approved Lists of Bacterial Names (Skerman et al., 1980) are inserted between quotation marks.

$\uparrow$ Type strains. 


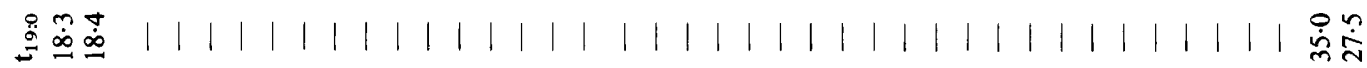

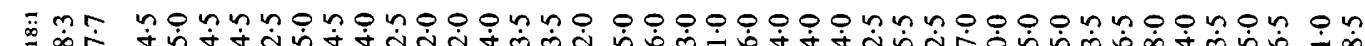

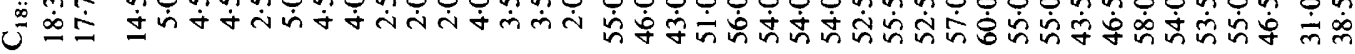

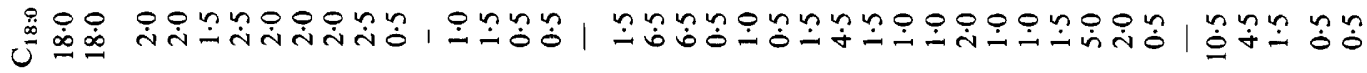

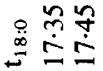

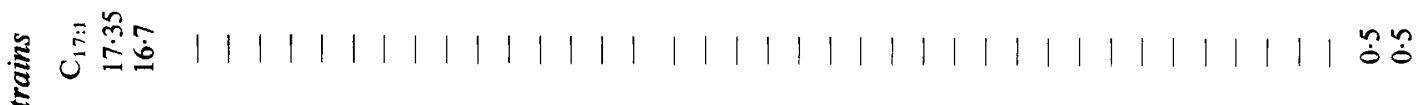
产 竞

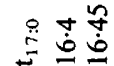

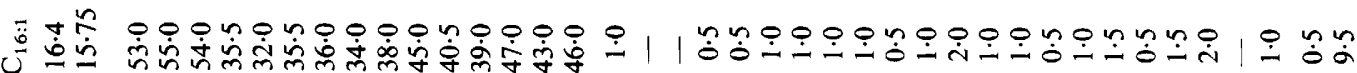

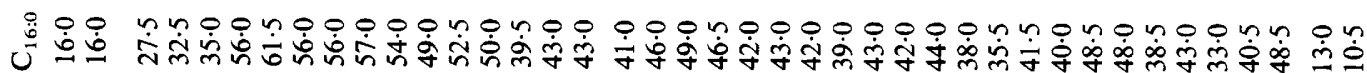

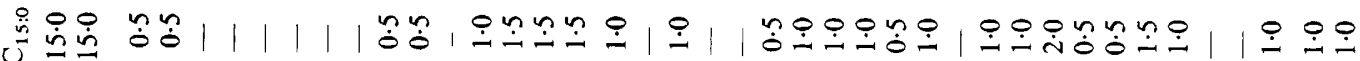

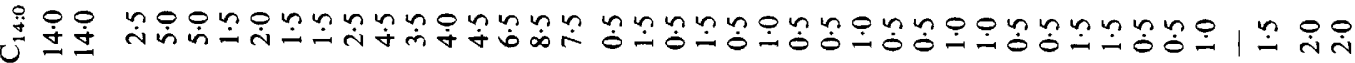

$\stackrel{\frac{\pi}{\circ}}{\frac{\pi}{3}}$

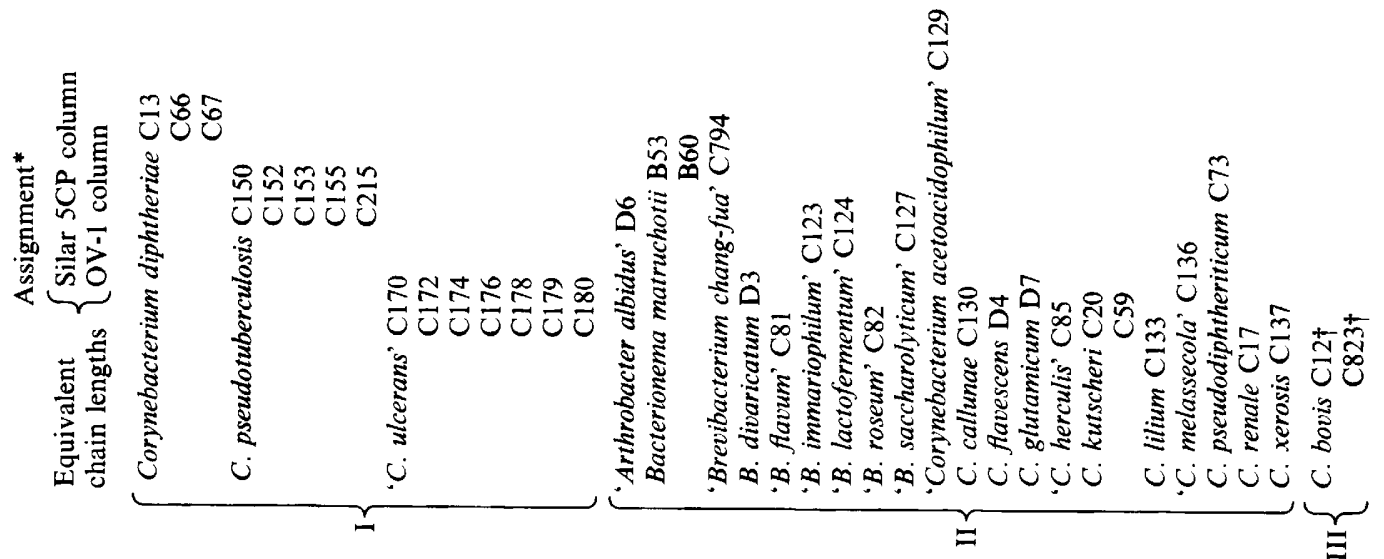




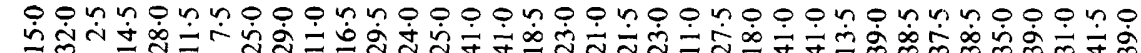

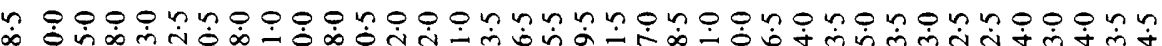

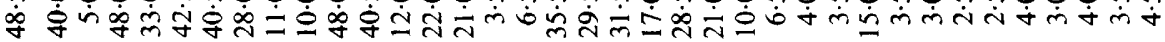

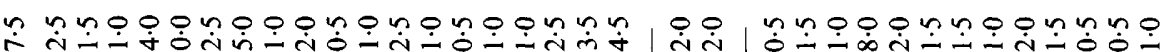
|

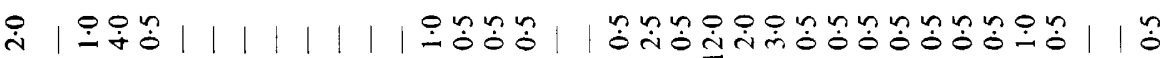

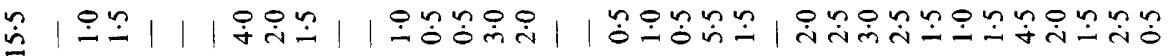
| | n 凹

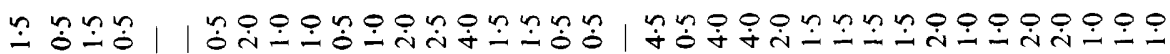

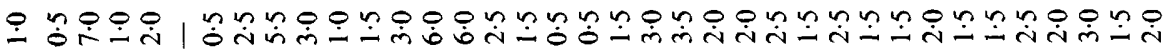

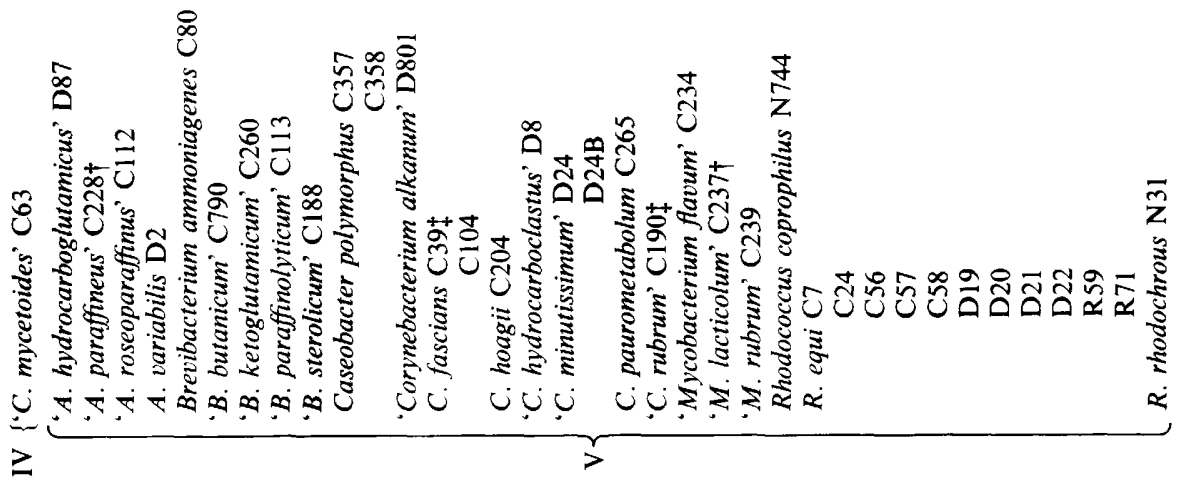


'C. mycetoides' are also distinctive as they contain side-chains ( $\alpha$-alkyl chains) with odd numbers of carbon atoms (Collins et al., 1982)

In addition to straight-chain and monounsaturated fatty acids, representatives of the genus Rhodococcus also possess 10-methyl branched acids (Minnikin et al., 1978). The recovery of major amounts of 10-methyloctadecanoic acid, and smaller homologues, from strains previously labelled C. equi, C. fascians, C. hoagii and 'C. rubrum' does not contradict the reclassification of these taxa in the genus Rhodococcus (Goodfellow \& Alderson, 1977; Goodfellow et al., 1982a, b). Representatives of the first three species mentioned above form a single DNA homology group (Suzuki et al., 1981) and it has been proposed, on the basis of chemical, numerical phenetic and genetical data, that $C$. hoagii be reduced to a synonym of $R$. equi (Goodfellow et al., 1982a). Strains labelled 'Arthrobacter hydrocarboglutamicus', 'A paraffineus', 'Brevibacterium butanicum', 'B. ketoglutamicum', 'B. paraffinolyticum', 'B. sterolicum', 'Corynebacterium alkanum', 'C. hydrocarboclastus', 'Mycobacterium lacticolum' and ' $M$. rubrum' also contain substantial amounts of 10-methyloctadecanoic acid (Table 2), have mycolic acids with similar chain lengths to those of most rhodococci (Collins et al., 1982) and should be reclassified in the genus Rhodococcus.

'Arthrobacter roseoparaffinus' $\mathrm{C} 112$ and 'A. variabilis' D2 also contain major amounts of 10 methyloctadecanoic acid (Table 2), but are in need of further study as they have mycolic acids intermediate in size between those of true corynebacteria and most rhodococci (Collins et al., 1982). Indeed, it must be stressed that a clear distinction cannot be made between Corynebacterium sensu stricto and Rhodococcus strains solely on the presence or absence of 10methyl branched acids, as strains of Brevibacterium ammoniagenes and Corynebacterium minutissimum', whose mycolic acids appear to be similar to those of corynebacteria (Collins et al., 1982), are similar to $C$. bovis in so far as they contain major amounts of 10methyloctadecanoic acid (Table 2).

The genus Caseobacter was introduced (Crombach, 1978) to accommodate 'grey-white' coryneform bacteria from cheese; the isolates contained meso-diaminopimelic acid, arabinose, galactose and mycolic acids in their walls. In the present study the Caseobacter polymorphus strains contained major amounts of straight-chain, monounsaturated and 10-methyloctadecanoic acids and could not be distinguished from rhodococci and related strains on this basis. The detailed taxonomic affinities of Caseobacter, therefore, remain unresolved, for while caseobacters contain short-chain mycolic acids (about $\mathrm{C}_{30}$ to $\mathrm{C}_{36}$; Collins et al., 1982) similar to those of most true corynebacteria, they have a DNA base composition similar to rhodococci (Crombach, 1978; Suzuki et al., 1981). Further comparative chemotaxonomic and molecular genetical studies are needed to clarify the affinities of Caseobacter and other mycolic acidcontaining taxa. Caseobacter polymorphus, however, has little DNA in common with either Corynebacterium glutamicum or Rhodococcus equi (Suzuki et al., 1981).

Corynebacterium paurometabolum $\mathrm{C} 265$ also contains significant amounts of 10-methyloctadecanoic acid in addition to straight-chain saturated and monounsaturated fatty acids (Table 2). This organism, however, can be clearly distinguished from both true corynebacteria and rhodococci in possessing some long $\left(\mathrm{C}_{68}\right.$ to $\left.\mathrm{C}_{76}\right)$, highly unsaturated ( 2 to 6 double bonds) mycolic acids (Collins \& Jones, 1982).

It is clear from this and earlier studies (Minnikin et al., 1978, 1979; Collins et al., 1980; Collins \& Jones, 1980) that fatty acid analyses provide data of value for both the classification and identification of coryneform and related bacteria. In particular, the presence of predominantly straight-chain and monounsaturated fatty acids in strains of Corynebacterium sensu stricto underlines their relationship with Mycobacterium, Nocardia and Rhodococcus and distinguishes them from Arthrobacter, Brevibacterium, Cellulomonas, Curtobacterium, Microbacterium and Oerskovia, all of which contain major amounts of iso- and anteiso-methyl branched-chain acids. Further, the discontinuous distribution of 10-methyl branched acids promises to be of value in the classification and identification of mycolic acid-containing bacteria.

We are indebted to colleagues who kindly provided cultures (Table 1). This investigation was supported, in part, by MRC grant G974/522/S and one of us (M.D.C.) gratefully acknowledges receipt of a Luccock Scholarship (Medical Scholarships and Research Committee, Faculty of Medicine, University of Newcastle upon Tyne). 


\section{REFERENCES}

Alshamaony, L., Goodfellow, M., Minnikin, D. E., Bowden, G. H. \& HaRdie, D. J. (1977). Fatty and mycolic acid composition of Bacterionema matruchotii and related organisms. Journal of General Microbiology 98, 205-213.

Brennan, P. J. \& Lehane, D. P. (1971). The phospholipids of corynebacteria. Lipids 6, 401-409.

Collins, M. D. (1982). Reclassification of Bacterionema matruchotii (Mendel) in the genus Corynebacterium, as Corynebacterium matruchotii comb. nov. Zentralblatt für Bakteriologie, Parasitenkunde, Infektionskrankheiten und Hygiene (I. Abteilung, Originale C) 3, 364-367

Collins, M. D. \& Jones, D. (1980). Lipids in the classification and identification of coryneform bacteria containing peptidoglycan based on 2,4diaminobutyric acid. Journal of Applied Bacteriology 48, 459-470.

Collins, M. D. \& Jones, D. (1982). Lipid composition of Corynebacterium paurometabolum (Steinhaus). FEMS Microbiology Letters 13, 13-16.

Collins, M. D., Pirouz, T., Goodfellow, M. \& MINNIKIN, D. E. (1977). Distribution of menaquinones in actinomycetes and corynebacteria. Journal of General Microbiology 100, 221-230.

Collins, M. D., Goodfellow, M. \& Minnikin, D. E. (1979). Isoprenoid quinones in the classification of coryneform and related bacteria. Journal of General Microbiology 110, 127-136.

Collins, M. D., Goodfellow, M. \& Minnikin, D. E. (1980). Fatty acid, isoprenoid quinone and polar lipid composition in the classification of Curtobacterium and related taxa. Journal of General Microbiology 118, 29-37.

Collins, M. D., Goodfellow, M. \& Minnikin, D. E. (1982). A survey of the structure of mycolic acids in Corynebacterium and related taxa. Journal of General Microbiology 128, 129-149.

СRомвасн, W. H. J. (1978). Caseobacter polymorphus gen.nov., sp.nov., a coryneform bacterium from cheese. International Journal of Systematic Bacteriology 28, 354-366.

Goodfellow, M. \& Alderson, G. (1977). The actinomycete-genus Rhodococcus: a home for the 'rhodochrous' complex. Journal of General Microbiology 100, 99-122.

Goodfellow, M., Collins, M. D. \& Minnikin, D. E. (1976). Thin-layer chromatographic analysis of mycolic acid and other long-chain components in whole-organism methanolysates of coryneform and related taxa. Journal of General Microbiology 96, 351358.

Goodfellow, M., Beckham, A. R. \& Barton, M. D. (1982a). Numerical classification of Rhodococcus equi and related actinomycetes. Journal of Applied Bacteriology (in the Press).

Goodfellow, M., Weaver, C. R. \& Minnikin, D. E. $(1982 b)$. Numerical classification of some rhodo- cocci, corynebacteria and related organisms. Journal of General Microbiology 128, 731-745.

JONES, D. (1975). A numerical taxonomic study of coryneform and related bacteria. Journal of General Microbiology 87, 52-96.

KATES, M. (1972). Techniques in Lipidology. Amsterdam: North Holland Publishing Co.

KEDDIE, R. M. \& CURE, G. L. (1977). The cell wall composition and distribution of free mycolic acids in named strains of coryneform bacteria and in isolates from various natural sources. Journal of Applied Bacteriology 42, 229-252.

KropPENSTEDT, R. M. \& KUTZNER, H. J. (1978). Biochemical taxonomy of some problem actinomycetes. Zentralblatt für Bakteriologie, Parasitenkunde, Infektionskrankheiten und Hygiene (Abteilung I) Suppl. 6, 125-133.

Lechevalier, M. P., De Bievre, C. \& Lechevalier, $H$. (1977). Chemotaxonomy of aerobic actinomycetes: phospholipid composition. Biochemical Systematics and Ecology 5, 249-260.

Maximescu, P., Oprisan, A., Pop, A. \& Potarac, E. (1974). Further studies on Corynebacterium species capable of producing diphtheria toxin ( $C$. diphtheriae, C. ulcerans and C.ovis). Journal of General Microbiology 82, 49-56.

Minnikin, D. E., Alshamaony, L. \& Goodfellow, M. (1975). Differentiation of Mycobacterium, Nocardia, and related taxa by thin-layer chromatographic analysis of whole-organism methanolysates. Journal of General Microbiology 88, 200-204.

Minnikin, D. E., Goodfellow, M. \& Collins, M. D. (1978). Lipid composition in the classification and identification of coryneform and related taxa. In Coryneform Bacteria, pp. 85-160. Edited by I. J. Bousfield \& A. G. Callely. London: Academic Press.

Minnikin, D. E., Collins, M. D. \& Goodfellow, M. (1979). Fatty acid and polar lipid composition in the classification of Cellulomonas, Oerskovia and related bacteria. Journal of Applied Bacteriology 47, 87-95.

Miwa, T. K., Mikolajczak, K. L., Earle, F. R. \& WolfF, I. A. (1960). Gas chromatographic characterization of fatty acids. Analytical Chemistry 32, 1739-1742.

Skerman, V. B. D., McGowan, V. \& Sneath, P. H. A. (1980). Approved lists of bacterial names. International Journal of Systematic Bacteriology 30, 225420.

Suzuki, K., Kaneko, T. \& Komagata, K. (1981). Deoxyribonucleic acid homologies among coryneform bacteria. International Journal of Systematic Bacteriology 31, 131-138.

Yamada, Y., Inouye, G., TAhara, Y. \& Kondo, K. (1976). The menaquinone system in the classification of coryneform and nocardioform bacteria and related organisms. Journal of General and Applied Microbiology 22, 203-214. 